\title{
Isokinetic evaluation of wrist muscle strength in patients of carpal tunnel syndrome
}

\author{
Karpal tünel sendromu hastalarında el bileği kas gücünün izokinetik değerlendirilmesi
}

\author{
Mehmet Ağırman, MD'., Adnan Kara, MD²., Oğuz Durmuş, MD'., \\ Illknur Saral, MD¹., Engin Çakar, MD'1 \\ 1Department of Physical Medicine and Rehabilitation, Medical Faculty of İstanbul Medipol University, İstanbul, Turkey \\ ${ }^{2}$ Department of Orthopedics and Traumatology, Medical Faculty of İstanbul Medipol University, İstanbul, Turkey
}

\section{ABSTRACT}

Objectives: This study aims to investigate the isokinetic characteristics of wrist strength in flexion, extension, supination, pronation, radial, and ulnar deviation in patients with moderate or severe carpal tunnel syndrome (CTS).

Patients and methods: Thirteen patients (23 hands) (2 males, 11 females; mean age 45 years; range 29 to 60 years) with moderate or severe CTS were compared to six healthy control subjects (12 hands) ( 2 males, 4 females; mean age 41 years; range 27 to 63 years) in this study, which was conducted between January 2016 and April 2016. Wrist flexion, extension, supination, pronation, radial, and ulnar deviation muscle strengths were measured at $30 \%$ second (5 sets) angular velocity with isokinetic dynamometer. Grip strength was measured with hand dynamometer (kilograms). Boston Questionnaire was used for clinical assessment.

Results: Grip strength ( $\mathrm{p}=0.003)$; wrist flexion $30 \%$ second $(\mathrm{p}=0.014)$; extension $30 \%$ second $(\mathrm{p}=0.016)$; and ulnar deviation $30 \%$ second $(\mathrm{p}=0.017)$ muscle strengths were lower in CTS patients compared with the control group. An evaluation according to symptom duration did not reveal any significant relationship in any of the isokinetic tests with the exception of pronation $30 \%$ second $(\mathrm{p}=0.039, \mathrm{r}=-0.432)$ and ulnar deviation $30 \%$ second $(\mathrm{p}=0.034, \mathrm{r}=0.443)$ in CTS patients. No significant relationship was found between Boston Questionnaire, grip strength, and isokinetic test results.

Conclusion: Quantitative wrist strength measurements with isokinetic dynamometers are beneficial in conservative exercise treatments and motor assessments of CTS patients.

Keywords: Carpal tunnel syndrome; hand strength; muscle strength dynamometer.

\section{ÖZ}

Amaç: Bu çalışmada orta veya ağır karpal tünel sendromu (KTS) hastalarında el bileğinin fleksiyon, ekstansiyon, supinasyon, pronasyon, radial ve ulnar deviyasyon kas gücünün izokinetik özellikleri araştırıldı.

Hastalar ve yöntemler: Ocak 2016-Nisan 2016 tarihleri arasında yapılan bu çalışmada orta veya ağır KTS olan 13 hasta $(23$ el) (2 erkek, 11 kadın; ort. yaş 45 yıl; dağılım 29-60 yıl) ile altı sağlıklı kontrol deneği (12 el) (2 erkek, 4 kadın; ort. yaş 41 yıl; dağılım 27-63 yıl) karşılaştırıldı. El bileği fleksiyon, ekstansiyon, supinasyon, pronasyon, radial ve ulnar deviasyon kas gücü izokinetik dinamometre ile $30 \%$ saniye (5 set) açısal hızda ölçüldü. Kavrama gücü el dinamometresi ile (kilogram) ölçüldü. Klinik değerlendirme için Boston Anketi kullanıldı.

Bulgular: Karpal tünel sendromu hastalarında kavrama gücü ( $\mathrm{p}=0.003)$; el bileği fleksiyonu $30 \%$ saniye $(\mathrm{p}=0.014)$; ekstansiyonu $30 \%$ saniye $(\mathrm{p}=0.016)$ ve ulnar deviasyonu $30 \%$ saniye $(\mathrm{p}=0.017)$ kas güçleri kontrol grubuna göre daha düşük idi. Semptom süresine göre yapılan değerlendirme, izokinetik testlerde pronasyon $30 \%$ saniye $(\mathrm{p}=0.039, \mathrm{r}=-0.432)$ ve ulnar deviasyon $30 \%$ saniye $(p=0.034, r=0.443)$ dişında KTS hastalarında anlamlı ilişki göstermedi. Boston Anketi, kavrama gücü ve izokinetik test sonuçları arasında anlamlı ilişki saptanmadi.

Sonuç: El bileği kas gücünün izokinetik dinamometreler ile sayısal olarak ölçülmesi KTS hastalarının konservatif egzersiz tedavileri ve motor değerlendirmelerinde faydalıdır. Anahtar sözcükler: Karpal tünel sendromu; el gücü; kas gücü dinamometresi.

- Received: May 30, 2016 Accepted: November 03, 2016

- Correspondence: Mehmet Ağırman, MD. İstanbul Medipol Üniversitesi Tıp Fakültesi, Fiziksel Tıp ve Rehabilitasyon Anabilim Dalı, 34214 Bağcılar, İstanbul, Turkey. Tel: +90 212 - 4607070 e-mail: mehmetagirman@yahoo.com 
The chronic compression of the median nerve in the carpal tunnel is responsible for median nerve ischemia and segmental demyelination, which results in carpal tunnel syndrome (CTS), the most commonly reported upper-limb entrapment neuropathy. ${ }^{[1]}$ Symptoms include a burning pain, tingling, and numbness in the median nerve distribution of the hand, as well as sensations of clumsiness and weakness, which worsen with activity. ${ }^{[2]}$ Individuals with CTS also complain of deficits in their daily activities, such as pinch and grip weakness, difficulty grasping small objects, and reduced fine motor control.

Assessment of grip and pinch strengths is the most common method used for CTS and some other clinical conditions in addition to clinical assessments, providing quantitative values for the examined muscles. ${ }^{[3,4]}$ Isokinetic muscle-strength tests assess the dynamic biomechanical functions of muscles differently from grip and pinch strengths. However, to the best of our knowledge, no study to date has used isokinetic tests to compare the results of wrist strength and CTS, and we hypothesized that CTS patients would exhibit greater weakness in the affected wrist in addition to the grip strength when compared to the healthy individuals. Therefore, in this study, we aimed to investigate the isokinetic characteristics of wrist strength in flexion, extension, supination, pronation, radial, and ulnar deviation in patients with moderate or severe CTS.

\section{PATIENTS AND METHODS}

This correlational, cross-sectional study was conducted between January 2016 and April 2016 at Medipol University, Faculty of Medicine with the participation of 13 moderate or severe CTS patients (23 hands) ( 2 males, 11 females; mean age 45 years; range 29 to 60 years) and six controls (12 hands) (2 males, 4 females; mean age 41 years; range 27 to 63 years). The study group was generated from referrals to outpatient clinics specializing in physical medicine and rehabilitation and in orthopedics and traumatology. The study protocol was approved by the Istanbul Medipol University, Faculty of Medicine Ethics Committee. A written informed consent was obtained from each patient. The study was conducted in accordance with the principles of the Declaration of Helsinki.

Patients who had clinical signs and symptoms of CTS were referred to an electroneuromyography (ENMG) laboratory for diagnosis. After the ENMG, patients were asked to participate in the study if they met the following criteria: (i) age above 18 years; (ii) ENMG diagnosis of moderate (abnormal median sensory latencies and prolongation of median motor distal latency) or severe (absence of median sensory response and prolonged median motor distal latencies or absent thenar compound muscle action potentials) CTS; (iii) no previous surgery; (iv) no injection for CTS within the previous three months; (v) no other musculoskeletal condition, such as fracture, ulnar or radial entrapment, lateral epicondylitis, and cervical radiculopathy; and (vi) no use of a wrist splint during the previous month. Exclusion criteria included CTS caused by systemic disease (e.g., diabetes mellitus or thyroid disease), pregnancy, and an inability to comply with isokinetic tests.

Six controls (12 hands) were matched based on age and hand dominance. These controls were recruited among the volunteers from healthy hospital staff who have no history of upper limb or neck pain, numbness or any neurologic disorder.

\section{Strength tests}

Tests were performed with the use of a testing dynamometer (HUMAC NORM, Version: 10.000.0039, CSMi, USA) and guidance of a rehabilitation medicine specialist to assess the isokinetic muscle strength of the wrist joint. The dynamometer was calibrated before the tests were conducted. While seated in an upright position, the patient's trunk, shoulder, and forearm were fastened with a belt to minimize body and joint movements, upper arm adducted, and forearm parallel to the floor $\left(90^{\circ}\right.$ elbow flexion). Patients performed five-set trials for each condition before the test. Peak torque values were measured in Newton meters, as the highest torque for each motion of five sets. During the test, patients were warned verbally to perform their best movements. Wrist flexion, extension, ulnar and radial deviations, and forearm supination and pronation were tested at $30 \%$ second (5 sets) angular velocity with the patients' maximum range of motions. A one-minute rest period was provided between testing speeds. Grip strength was measured with the use of a hydraulic hand dynamometer (Baseline Instruments ${ }^{\circledR}$ ). The mean value of the measurements was recorded in kilograms (kg).

All patients completed a Boston Questionnaire $(B Q)$, which is a self-administered questionnaire designed to assess the severity of CTS. The BQ, which has been shown to be reliable and responsive when used with CTS patients, has Turkish validity. ${ }^{[5]}$

\section{Statistical analysis}

Statistical analyses were performed using SPSS version 11.5.0 statistical software for the social sciences (SPSS Inc., Chicago, IL, USA). Isokinetic and grip 
TABLE I

Differences in muscle strength of dominant and nondominant hands in patients with carpal tunnel syndrome

\begin{tabular}{|c|c|c|c|}
\hline & Dominant hand $(n=12)$ & Nondominant hand $(\mathrm{n}=11)$ & \\
\hline & Mean $\pm S D$ & Mean $\pm S D$ & $p$ \\
\hline Grip strength (kg) & $21 \pm 3.3$ & $20.7 \pm 3.5$ & 0.80 \\
\hline \multicolumn{4}{|l|}{ Peak torques (Nm) } \\
\hline Flexion $30 \%$ second & $8.9 \pm 2.2$ & $9.2 \pm 3.7$ & 0.95 \\
\hline Extension $30 \%$ second & $7.2 \pm 4.6$ & $5.7 \pm 2.3$ & 0.43 \\
\hline Pronation $30 \%$ second & $7.3 \pm 4.1$ & $6.4 \pm 3.5$ & 0.66 \\
\hline Supination $30 \%$ second & $5.4 \pm 3.4$ & $5.3 \pm 2.8$ & 0.92 \\
\hline Radial deviation $30 \%$ second & $8.1 \pm 2.5$ & $10.2 \pm 5.4$ & 0.35 \\
\hline Ulnar deviation $30 \%$ second & $9.2 \pm 3.5$ & $8.1 \pm 3.3$ & 0.57 \\
\hline
\end{tabular}

strengths of the two groups were compared using the Mann-Whitney U test. The Spearman's correlation coefficient test was used for the correlate symptom duration, BQ scores, and grip strength with isokinetic strength. P-values lower than 0.05 were accepted as statistically significant.

\section{RESULTS}

All participants were right-hand dominant. Ten patients had bilateral CTS, and three patients had unilateral CTS (two on the right side and one on the left side). A comparison of the results of the dominant and nondominant hands in patients with CTS revealed no significant differences within any of the parameters (Table I). Table II presents a comparison of the grip and isokinetic strength of the CTS patients and the controls. When compared with the healthy controls, the patients with CTS showed lower scores in grip strength ( $\mathrm{p}=0.003)$; wrist flexion $30^{\circ}$ /second $(\mathrm{p}=0.014)$; extension $30^{\circ} /$ second $(\mathrm{p}=0.016)$; and ulnar deviation $30 \%$ second $(\mathrm{p}=0.017)$.
Table III summarizes the correlations of the isokinetic results with symptom duration, $B Q$, and grip strength in CTS patients. The mean symptom duration (month), Boston Symptom Score (BSS), Boston Functional Score (BFS), and grip strength $(\mathrm{kg})$ were 24.3, 32.3, 22.6 and 20.8, respectively, in patients with CTS. No significant relationships were found in the BSS, BFS, grip strength, and isokinetic test results in CTS patients.

In terms of symptom duration, no significant relationships were found in any of the isokinetic tests, with the exception of the pronation $30 \%$ second $(\mathrm{p}=0.039, \mathrm{r}=-0.432)$, and ulnar deviation $30 \%$ second $(\mathrm{p}=0.034, \mathrm{r}=0.443)$ in CTS patients.

\section{DISCUSSION}

The findings of the current study demonstrated that isokinetic wrist flexion, extension, ulnar deviation, and grip strength were significantly decreased in patients with moderate or severe CTS when compared with the control group. No significant relationships

TABLE II

Differences in dynamometric measurements of patients and controls

\begin{tabular}{|c|c|c|c|c|}
\hline & CTS patients $(n=23)$ & Controls $(n=12)$ & & \\
\hline & Mean $\pm S D$ & Mean $\pm S D$ & $p$ & $z$ \\
\hline Age (year) & $45.0 \pm 6.9$ & $41.2 \pm 10.6$ & 0.09 & -1.6 \\
\hline Grip strength (kg) & $20.8 \pm 3.3$ & $24.6 \pm 3.2$ & 0.003 & -2.9 \\
\hline \multicolumn{5}{|l|}{ Peak torques (Nm) } \\
\hline Flexion $30 \%$ second & $10.0 \pm 3.0$ & $12.5 \pm 4.3$ & 0.014 & -2.4 \\
\hline Extension $30 \%$ second & $6.5 \pm 3.7$ & $8.9 \pm 2.9$ & 0.016 & -2.4 \\
\hline Pronation $30 \%$ second & $6.9 \pm 3.7$ & $5.5 \pm 2.3$ & 0.42 & -0.8 \\
\hline Supination $30 \%$ second & $5.3 \pm 3.1$ & $6.6 \pm 2.5$ & 0.18 & -1.3 \\
\hline Radial deviation $30 \%$ second & $9.1 \pm 4.2$ & $11.5 \pm 3.9$ & 0.06 & -1.8 \\
\hline Ulnar deviation $30 \%$ second & $8.7 \pm 3.4$ & $11.9 \pm 3.9$ & 0.017 & -2.3 \\
\hline
\end{tabular}

CTS: Carpal tunnel syndrome; SD: Standard deviation. 
TABLE III

Correlation of isokinetic results with symptom duration, Boston Questionnaire scores, and grip strength in patients with carpal tunnel syndrome

\begin{tabular}{|c|c|c|c|c|c|c|c|c|}
\hline & \multicolumn{2}{|c|}{$\begin{array}{l}\text { Symptom duration } \\
\text { (month) }(\mathrm{n}=23)\end{array}$} & \multicolumn{2}{|c|}{$\begin{array}{l}\text { Boston symptom } \\
\text { score }(n=23)\end{array}$} & \multicolumn{2}{|c|}{$\begin{array}{l}\text { Boston functional } \\
\text { score }(n=23)\end{array}$} & \multicolumn{2}{|c|}{$\begin{array}{l}\text { Grip }(\mathrm{kg}) \\
(\mathrm{n}=23)\end{array}$} \\
\hline & $p$ & $r$ & $p$ & $r$ & $p$ & $\mathrm{r}$ & $p$ & $\mathrm{r}$ \\
\hline Flexion $30 \%$ second & 0.223 & -0.264 & 0.607 & -0.113 & 0.854 & 0.041 & 0.736 & -0.074 \\
\hline Extension $30 \%$ second & 0.293 & -0.229 & 0.106 & 0.346 & 0.149 & 0.311 & 0.767 & 0.065 \\
\hline Pronation $30 \%$ second & 0.006 & -0.552 & 0.778 & 0.062 & 0.942 & 0.016 & 0.463 & -0.161 \\
\hline Supination $30 \%$ second & 0.053 & -0.408 & 0.235 & 0.258 & 0.11 & 0.342 & 0.381 & -0.192 \\
\hline Radial deviation $30 \%$ second & 0.646 & -0.101 & 0.663 & 0.096 & 0.394 & 0.187 & 0.635 & 0.105 \\
\hline Ulnar deviation $30 \%$ second & 0.099 & -0.353 & 0.945 & -0.015 & 0.758 & -0.068 & 0.983 & 0.005 \\
\hline Mean $\pm S D$ & \multicolumn{2}{|c|}{$24.3 \pm 21.5$} & \multicolumn{2}{|c|}{$32.3 \pm 5.2$} & \multicolumn{2}{|c|}{$22.6 \pm 4.1$} & \multicolumn{2}{|c|}{$20.8 \pm 3.3$} \\
\hline
\end{tabular}

SD: Standard deviation.

were found between the isokinetic tests and the BSS, BFS, and grip strength in CTS patients.

Decreased muscle strength in patients with CTS is caused by various factors, such as denervation of the median nerve fibers that innervate the hand muscles, pain, and numbness. Szabo and Steinberg ${ }^{[6]}$ argue that the tendency to drop items can be related to a decrease in sensitivity and may be secondary to thenar weakness. At the same time, studies described in the CTS literature have explored the relationship between grip force and hand's sensory function. ${ }^{[7]}$ You et al. ${ }^{[8]}$ divided the symptoms into two groups: primary (numbness, tingling, and nocturnal symptoms) and secondary (pain, weakness, and clumsiness) and concluded that secondary symptoms are less correlated with the electrophysiological findings of median nerve injury. In a comparison of the motor function of 203 hands of CTS patients with the sensory symptoms and neurographic measures of the median nerve, Tamburin et al. ${ }^{[9]}$ concluded that hand weakness was strongly correlated with sensory symptoms and found no association with the electrophysiologic results. However, the authors measured motor outcomes via the self-administered BQ. The lack of relationship between the clinical scales and isokinetic measures (except the symptom duration) suggests that the clinical scales are not correlated with the muscle strength.

In this study, no significant differences were found between the BSS, BFS, grip strength, symptom duration, and isokinetic test results, with the exception of pronation and ulnar deviation in symptom duration. Our results confirmed that muscle weakness is not correlated with just the median nerve innervated muscles, as is the grip strength in patients with CTS. Forearm supinators, pronators, wrist flexors, and extensor, ulnar, and radial deviators are innervated by the median, ulnar, and radial nerves. In fact, gripmuscle strength does not affect CTS because of the median nerve's innervation proximal to the carpal tunnel. ${ }^{[3]}$ Additionally, the sensory innervation of the hand and wrist is provided by the radial, median, and ulnar nerves. Another reason for this discrepancy is that conventional electrophysiological studies may not accurately reflect the nerve damage. ${ }^{[10]}$

Isokinetic tests measure the strength dynamically and provide more detailed information about agonist/antagonist muscle balance. Only two prospective studies have investigated the isokinetic muscle strength of the hand in patients with CTS. Kaymak et al. ${ }^{[11]}$ found that grip and pinch strengths were significantly reduced in CTS patients when compared with controls who were measured with an isokinetic dynamometer; however, wrist muscle strength was not examined. Similarly, grip strength was significantly decreased in this study when compared with the controls. Reichard et al. ${ }^{[12]}$ used isokinetic measurements to compare the strength of wrist flexors and extensors of CTS patients and controls to determine the utility of full-range and short-range wrist motion. The authors found more significantly decreased muscle strength in flexion than in extension. In addition to Reichard et al., ${ }^{[12]}$ we assessed the ulnar-radial deviation, supination, and pronation strengths and we compared the isokinetic results with the clinical findings.

Although patients with ulnar entrapment symptoms and signs were excluded in this study, decreased muscle strength in ulnar deviation was shown in addition to that in wrist flexion and extension. Therefore, it is more probable that motor outcomes, such as pain, sensory impairments, 
small-fiber damage, hand-muscle interaction, and an inability to use the hands are associated with complex structures in CTS patients. Exercise treatment includes nerve and tendon gliding exercises and carpal-bone and soft-tissue mobilization. ${ }^{[13]}$ However, to our knowledge, no study to date has evaluated wrist-muscle-strengthening exercises in the conservative treatment of CTS. Strengthening of the flexor, extensor, and ulnar deviator muscles with nerve- and tendon-gliding exercises can be used during rehabilitation and to measure motor outcomes in CTS patients.

Immobilization is a well-known condition in muscle weakness. Splinting, which is the most commonly recommended conservative treatment option for the CTS, restricts wrist movements and decreases grip strength. ${ }^{[14,15]}$ In order to minimize the impact of nerve injury and immobilization, unsplinted patients with moderate or severe CTS, and who demonstrated electrodiagnostic motor and sensory deficits, were selected for the study.

The major limitation of our study was its rather small sample size. However, the strengths of our study were its measurements of the controls, its use of valid isokinetic measures, and its evaluations of the functional status of patients.

In conclusion, the current study shows that moderate or severe CTS causes muscle weakness in wrist flexion, extension, and ulnar deviation, as well as deficits in grip strength, as demonstrated through isokinetic tests. Although the clinical efficacy of weakness of wrist-muscle requires further studies, quantitative wrist strength measurements with isokinetic dynamometers might be helpful in the context of conservative exercise treatment and as a motor outcome in CTS patients.

\section{Acknowledgement}

The authors thank Dr. Mehmet Enes Gokler, Eskisehir Osmangazi University, Department of Public Health and Dr. Ahmet Salim Göktepe, Istanbul Medipol University, Department of Physical Medicine and Rehabilitation for their contribution in our statistical analysis.

\section{Declaration of conflicting interests}

The authors declared no conflicts of interest with respect to the authorship and/or publication of this article.

\section{Funding}

The authors received no financial support for the research and/or authorship of this article.

\section{REFERENCES}

1. Yeşil M, Bacakaoğlu AK, Doğan M. Are myofibroblasts activated in idiopathic carpal tunnel syndrome? an immunohistochemical study. Eklem Hastalik Cerrahisi 2014;25:133-40.

2. Aroori S, Spence RA. Carpal tunnel syndrome. Ulster Med J 2008;77:6-17.

3. Geere J, Chester R, Kale S, Jerosch-Herold C. Power grip, pinch grip, manual muscle testing or thenar atrophy - which should be assessed as a motor outcome after carpal tunnel decompression? A systematic review. BMC Musculoskelet Disord 2007;8:114.

4. Turan S, Çankaya D, Yılmaz S, Karakuş D, Dündar A, Özdemir G. Effect of ulnar styloid fracture on outcomes after conservative treatment of distal radius fracture. Eklem Hastalik Cerrahisi 2016;27:87-93.

5. Sezgin M, Incel NA, Serhan S, Camdeviren H, As I, Erdoğan C. Assessment of symptom severity and functional status in patients with carpal tunnel syndrome: reliability and functionality of the Turkish version of the Boston Questionnaire. Disabil Rehabil 2006;28:1281-5.

6. Szabo RM, Steinberg DR. Nerve Entrapment Syndromes in the Wrist. J Am Acad Orthop Surg 1994;2:115-123.

7. Johansson RS, Westling G. Signals in tactile afferents from the fingers eliciting adaptive motor responses during precision grip. Exp Brain Res 1987;66:141-54.

8. You H, Simmons Z, Freivalds A, Kothari MJ, Naidu SH. Relationships between clinical symptom severity scales and nerve conduction measures in carpal tunnel syndrome. Muscle Nerve 1999;22:497-501.

9. Tamburin S, Cacciatori C, Marani S, Zanette G. Pain and motor function in carpal tunnel syndrome: a clinical, neurophysiological and psychophysical study. J Neurol 2008;255:1636-43.

10. Bulut T, Sener U, Yağdi S, Kazimoğlu C, Sener M. Relationship between clinical and electrophysiological results in surgically treated carpal tunnel syndrome. Eklem Hastalik Cerrahisi 2011;22:140-4.

11. Kaymak B, Inanici F, Ozçakar L, Cetin A, Akinci A, Hasçelik Z. Hand strengths in carpal tunnel syndrome. J Hand Surg Eur Vol 2008;33:327-31.

12. Reichard B, Katz-Leurer M, Rubinstein M, Croisier JL, Dvir Z. Short range of motion isokinetic testing of wrist flexor and extensor strength in normal subjects and patients with carpal tunnel syndrome. J Strength Cond Res 2010;24:1866-73.

13. Akalin E, El O, Peker O, Senocak O, Tamci S, Gülbahar $S$, et al. Treatment of carpal tunnel syndrome with nerve and tendon gliding exercises. Am J Phys Med Rehabil 2002;81:108-13.

14. Bulut GT, Caglar NS, Aytekin E, Ozgonenel L, Tutun S, Demir SE. Comparison of static wrist splint with static wrist and metacarpophalangeal splint in carpal tunnel syndrome. J Back Musculoskelet Rehabil 2015;28:761-7.

15. Page MJ, Massy-Westropp N, O'Connor D, Pitt V. Splinting for carpal tunnel syndrome. Cochrane Database Syst Rev 2012;11:7. 